\title{
Congenital simple hamartoma of the retinal pigment epithelium: a case report
}

\section{Hamartoma congênito simples do epitéilo pigmentado da retina: relato de caso}

\author{
Mariana Rossi Thorell ${ }^{1}$, Vinicius Ferreira Kniggendorf ${ }^{2}$, Luis Augusto Arana ${ }^{3}$, Alexandre Achille Grandinetti ${ }^{2}$
}

\begin{abstract}
We report the case of a 56-year-old woman who presented for a routine ophthalmological examination without visual symptoms and had a unilateral black retinal lesion that was detected by clinical examination. Fluorescein angiography and optical coherence tomography findings were compatible with a congenital simple hamartoma of the retinal pigment epithelium. It is very important to detect this tumor and differentiate it from other pigmented fundus lesions that can compromise visual function or result in systemic conditions such as those caused by malignant tumors.
\end{abstract}

Keywords: Hamartoma/pathology; Retinal pigment epithelium; Retinal diseases; Congenital abnormalities; Tomography, optical coherence; Case report

\section{RESUMO}

Relato de um caso de paciente feminina de 56 anos que compareceu a uma consulta oftalmológica de rotina sem sintomas visuais e apresentando uma lesão retiniana preta, unilateral, detectada ao exame clínico. As características da angiografia fluoresceínica e da tomografia de coerência óptica foram compativeis com hamartoma congênito simples do epitélio pigmentado da retina. É muito importante detectar este tumor e diferenciá-lo de outras lesões fundoscópicas pigmentadas que podem comprometer a função visual ou, além disso, afetar o paciente sistemicamente como em tumores malignos.

Descritores: Hamartoma; Epitélio pigmentado da retina; Doenças retinianas; Anormalidades congênitas; Doenças retinianas; Tomografia de coerência óptica; Relato de caso

\section{INTRODUCTION}

Congenital simple hamartoma of the retinal pigment epithelium (CSHRPE) is an uncommon condition, and few cases have been described in the literature ${ }^{(1,2)}$. It was first discussed by Laqua in $1981^{(3)}$, and Gass reported three similar cases that he later published in a review of focal congenital anomalies of the retinal pigment epithelium (RPE)(4). This lesion has particular features on fundoscopic examination, fluorescein angiography (FA), and optical coherence tomography $(\mathrm{OCT})^{(5,6)}$.

Tumors of the RPE include congenital hamartoma, congenital hypertrophy, combined hamartoma of the retina and RPE, and adenoma or adenocarcinoma ${ }^{(7,8)}$. In one study, several authors ${ }^{(9)}$ reported on five cases classified as CSHRPE according to their clinical features; all of these lesions maintained a stable pattern during the follow-up period.

Here we describe a case of an asymptomatic 56-year-old woman with a unilateral circumscribed and pigmented fundus lesion suggestive of CSHRPE on clinical examination and confirmed by FA and OCT.

\section{CASE REPORT}

A 56-year-old woman was referred for a routine ophthalmic examination to our institution because of a 20-year history of type 2 diabetes treated with insulin. The Snellen best-corrected visual acuity was 20/20 in both eyes, which did not require correction in the right eye and was corrected with a prescription of $+0.75-0.25 \times 130^{\circ}$ in the left. Biomicroscopy examination was normal, and the intraocular pressure corresponded to $12 \mathrm{mmHg}$ and $10 \mathrm{mmHg}$ in her right and left eyes, respectively. Indirect ophthalmoscopy in the right eye was normal, and in the left eye, there was a circumscribed black posterior pole tumor that was inferotemporal to the fovea. There was no evidence of macular edema, traction, retinal exudation, or subretinal fluid.

Fluorescein angiography and OCT were performed. Angiography revealed a nonfluorescent lesion during all the phases of the examination, including the late phases (Figure 1). OCT revealed an abruptly elevated hyper-reflective mass with deep optical shadowing (Figure 2). The diagnosis was compatible with CSHRPE, and the patient was followed by observation.

\section{DISCUSSION}

CSHRPE is a benign tumor that is incidentally diagnosed and involves all layers of the retina. This hamartoma is presumed to be a congenital lesion. It is a rare tumor that can be detected during routine fundus ocular examination. On clinical examination, it appears as a solitary macular lesion that is darkly pigmented, well-defined, and involves the full thickness of the retina. Although FA findings were unremarkable in the present case, hyperfluorescence is occasionally observed in the late phases ${ }^{(1,2)}$. OCT typically shows a complete blockage of optical transmission. 

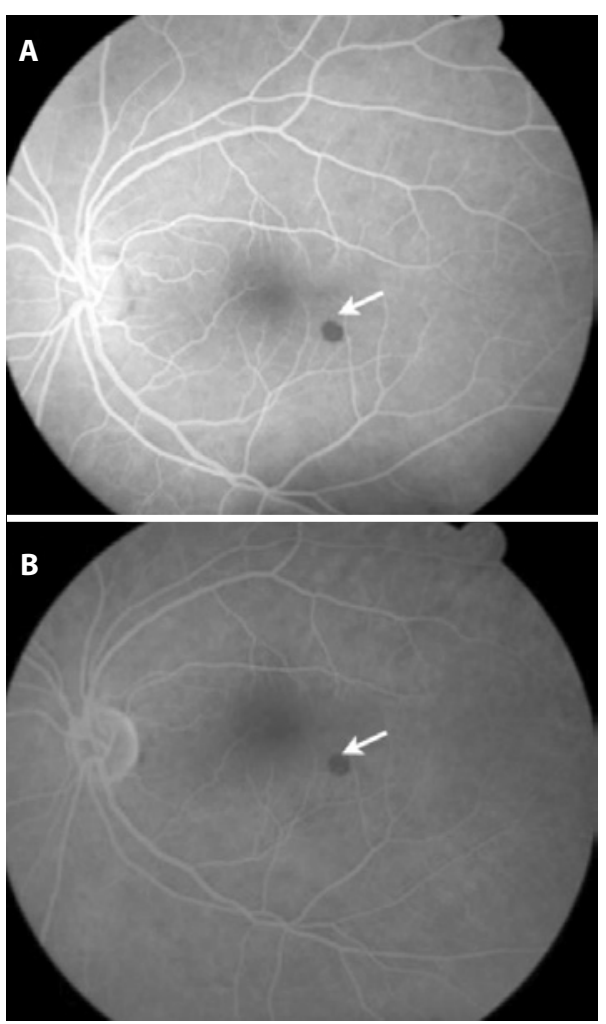

Figure 1. Fluorescein angiography of the left eye. A well-circumscribed lesion located inferotemporal to the fovea shows the absence of leakage and the presence of fluorescence blockage.

As noted in other reported cases, in this patient, CSHRPE remained stable in size and clinical aspects during the 12 months of follow-up, and the patient remains asymptomatic and without changes in visual acuity. Because of these features, adults are generally diagnosed at an advanced age.

Differential diagnoses include the following: combined hamartoma of the retina and RPE, congenital hypertrophy of the RPE (CHRPE), adenoma or adenocarcinoma of the RPE, hyperplasia of the RPE, intraretinal foreign body, and retinal invasion from an underlying choroidal nevus (melanocytoma) or choroidal melanoma ${ }^{(2)}$. All these can be ruled out by clinical and complementary examinations, as observed in the described patient.

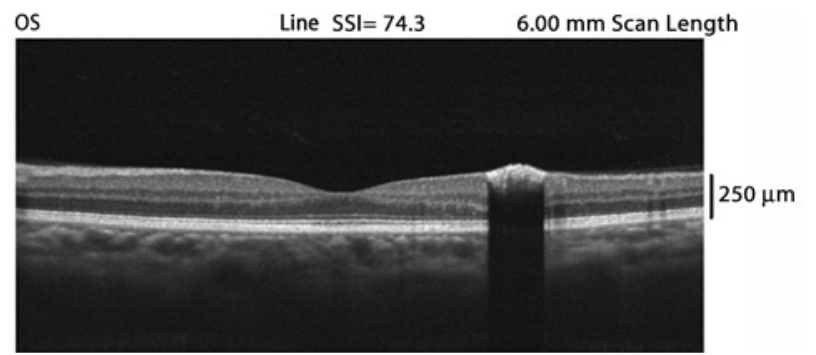

Figure 2. Optical coherence tomography. Slight elevation of the retina is observed at the location of the lesion, which is protruding into the vitreous cavity and shows increased optical reflectivity on its inner surface, with deep optical shadowing of the remaining retina and the entire choroid.

OCT is a useful noninvasive examination that can help in diagnosis and provide information about additional features such as vitreoretinal adhesion ${ }^{(10)}$.

In conclusion, it is very important to identify congenital simple hamartomas of the RPE and follow these patients over the long-term to rule out tumor growth and suspicious malignant features.

\section{REFERENCES}

1. Lopez JM, Guerrero P. Congenital simple hamartoma of the retinal pigment epithelium: optical coherence tomography and angiography features. Retina. 2006;26(6): 704-6.

2. Shields CL, Materin MA, Shields JA. Review of optical coherence tomography for intraocular tumors. Curr Opin Ophthalmol. 2005;16(3):141-54.

3. Laqua H. Tumors and tumor-like lesions of the retinal pigment epithelium. Ophthalmologica. 1981;183(1):34-8.

4. Gass JD. Focal congenital anomalies of the retinal pigment epithelium. Eye (Lond). 1989;3(Pt 1):1-18

5. Madgula IM, Adatia FA, Sagoo MS, Wescott M. Simple hamartoma of the retinal pigment epithelium in a man of African descent. Can J Ophthalmol. 2009:44(4):35-6.

6. Shields CL, Materin MA, Karatza EC, Shields JA. Optical coherence tomography of congenital simple hamartoma of the retinal pigment epithelium. Retina. 2004;24(2):327-8.

7. Souissi K, El Afrit MA, Kraiem A. Congenital retinal arterial macrovessel and congenital hamartoma of the retinal pigment epithelium. J Pediatr Ophthalmol Strabismus. 2006; 43(3):181-2.

8. Shields JA, Shields CL. Atlas of intraocular tumors. Philadelphia: Lippincott Williams \& Wilkins; 1999

9. Shields CL, Shields JA, Marr BP, Sperber DE, Gass JDM. Congenital simple hamartoma of the retinal pigment epithelium - a study of five cases. Ophthalmology. 2003; 110(5):1005-11.

10. Shukla D, Ambatkar S, Jethani J, Kim R. Optical coherence tomography in presumed congenital simple hamartoma of the retinal pigment epithelium. Am J Ophthalmol, 2005;139(5):945-7. 